\title{
Mathematic model of three-phase induction machine connected to advanced inverter for traction system for electric trolley
}

\author{
LIVIU S. BOCÎI and VALENTIN MÜLLER \\ University "Aurel Vlaicu” of Arad, Department of Automation, \\ Automotive and Rolling Stock 310330 Arad, Elena Drăgoi Street, nº 2, Romania \\ Manuscript received on February 2, 2011; accepted for publication on November 1, 2012
}

\begin{abstract}
This paper establishes a mathematical model of induction machine connected to a frequency inverter necessary to adjust the electric motor drive. The mathematical model based on the Park's theory allows the analysis of the whole spectrum (electric car - frequency inverter) to drive the electric trolley bus made on ASTRA Bus Arad (Romania). To remove higher order harmonics, the PWM waveform of supply voltage is used, set in the general case. Operating characteristics of electric motor drive are set to sub-nominal frequency ( $\mathrm{f}<50 \mathrm{~Hz}$ ) and for different angles of the control switching elements in the construction of the inverter. Tensions in the stator of the equivalent machine are determined by three components: the fundamental component; the second component corresponding to the higher order harmonics, which rotate in direct connection; and the appropriate third component of higher order harmonics, which are rotated in reverse. The mathematical model developed will help to determine the harmonics which have a negative influence on the performance of the electric engine and also determines the control angle of the switching elements to remove these harmonics, (Bele 2007).
\end{abstract}

Key words: induction engine, operating characteristics, mathematic model, trolley bus.

\section{INTRODUCTION}

The use of three-phase induction machine in the electric traction trolley is determined by: design simplicity, low cost price, high operational safety, and high technical performance (starting torque, high efficiency, etc.), (Bele 2007).

To improve the performance of the induction machine to change the drive speed is necessary to change the voltage and frequency according to system requirements traction.

Static frequency converters cause the voltages or currents, besides containing the fundamental harmonic and higher harmonics. Low harmonic content of output voltage, output current respectively, and high dynamic performance obtained from static frequency converters, based on the principle of inverters in the pulse duration modulation (PWM) as a sine law, promote the use of traction converters electricity. Using the command pulse duration modulated, pulse frequency is limited to $450 \mathrm{~Hz}$ if we use fast thyristors (Păpuşoiu 2003).

Correspondence to: Liviu Sevastian Bocîi

E-mail: bociis@yahoo.com 
The PWM principle applies especially to the static frequency converter with voltage intermediate circuit constant and very rarely converters with constant current designed for supply voltage and variable frequency induction motor rotor cage.

Power induction machine by static frequency converters requires analysis phase electrical machine functioning as the stationary regime consists of a "chain" of transient.

The study is done based on the transitional arrangements of the two axes theory established by Park, where the induction machine equations are written with respect to time.

\section{MATHEMATICAL MODEL OF THREE-PHASE INDUCTION MACHINE}

In theory the two axes, three-phase induction machine is equivalent to an induction machine with stator windings and rotor $\mathrm{d}$ and $\mathrm{q}$ axes arranged, fixed to the stator rotating magnetic field (Figure 1).

According to Figure 1 for the stator and rotor equations are:

$$
\left\{\begin{array}{c}
\mathrm{u}_{\mathrm{d}}=\mathrm{R}_{1} \mathrm{i}_{\mathrm{d}}+\frac{\mathrm{d} \psi_{\mathrm{d}}}{\mathrm{dt}}-\omega_{1} \psi_{\mathrm{q}} \\
\mathrm{u}_{\mathrm{q}}=\mathrm{R}_{1} \mathrm{i}_{\mathrm{q}}+\frac{\mathrm{d} \psi_{\mathrm{q}}}{\mathrm{dt}}-\omega_{1} \psi_{\mathrm{d}} \\
\mathrm{u}_{\mathrm{dr}}=\mathrm{R}_{2} \mathrm{i}_{\mathrm{dr}}+\frac{\mathrm{d} \psi_{\mathrm{dr}}}{\mathrm{dt}}-\left(\omega_{1}-\omega\right) \psi_{\mathrm{qr}} \\
\mathrm{u}_{\mathrm{qr}}=\mathrm{R}_{2} \mathrm{i}_{\mathrm{qr}}+\frac{\mathrm{d} \psi_{\mathrm{qr}}}{\mathrm{dt}}-\left(\omega_{1}-\omega\right) \psi_{\mathrm{dr}}
\end{array}\right.
$$

Where the stator and rotor magnetic flows are:

$$
\left\{\begin{array}{l}
\psi_{\mathrm{q}}=\mathrm{L}_{1 \sigma} \cdot \mathrm{i}_{\mathrm{d}}+\mathrm{L}_{1 \mathrm{~h}} \cdot\left(\mathrm{i}_{\mathrm{d}}+\mathrm{i}_{\mathrm{dr}}\right) \\
\psi_{\mathrm{q}}=\mathrm{L}_{1 \sigma} \cdot \mathrm{i}_{\mathrm{q}}+\mathrm{L}_{1 \mathrm{~h}} \cdot\left(\mathrm{i}_{\mathrm{q}}+\mathrm{i}_{\mathrm{qr}}\right) \\
\psi_{\mathrm{dr}}=\mathrm{L}_{2 \sigma} \cdot \mathrm{i}_{\mathrm{dr}}+\mathrm{L}_{1 \mathrm{~h}} \cdot\left(\mathrm{i}_{\mathrm{d}}+\mathrm{i}_{\mathrm{dr}}\right) \\
\psi_{\mathrm{qr}}=\mathrm{L}_{2 \sigma} \cdot \mathrm{i}_{\mathrm{qr}}+\mathrm{L}_{1 \mathrm{~h}} \cdot\left(\mathrm{i}_{\mathrm{q}}+\mathrm{i}_{\mathrm{qr}}\right)
\end{array}\right.
$$

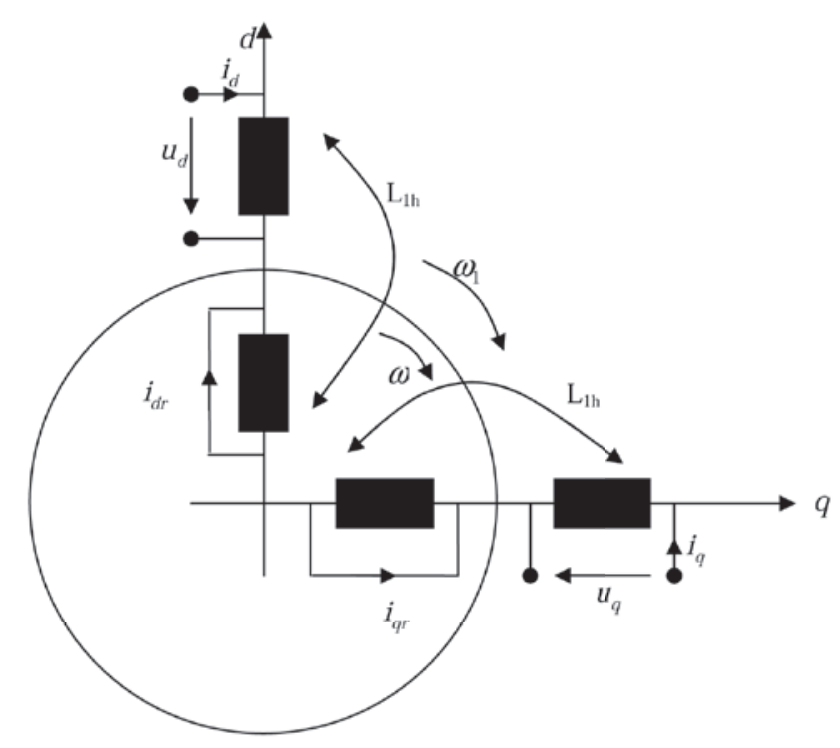

Figure 1 - Equivalent induction machine. 
Electrical parameters involved in equations (1) and (2) are:

$\mathrm{R}_{1}$ - stator phase resistance;

$\mathrm{R}_{2}$ - phase resistance of the rotor to the stator;

$\mathrm{L}_{1 \sigma^{-}}$leakage inductance of stator phase;

$\mathrm{L}_{2 \sigma^{-}}$phase leakage inductance of the rotor to the stator;

$\mathrm{L}_{1 \mathrm{~h}}$ - principal leakage;

$\omega_{1}, \omega$ - angular velocity of the stator magnetic field, and in the engine.

The voltage-current equations plus the equation of motion determined by:

$$
\mathrm{M}-\mathrm{M}_{\mathrm{m}}+\left(\frac{\omega_{1}}{\omega_{1 \mathrm{~N}}}\right)^{2}=\frac{\mathrm{J}}{\mathrm{p}_{1}} \cdot \frac{\mathrm{d} \omega}{\mathrm{dt}}
$$

where the electromeganetic couple is determined by the following relation (Dordea 2002):

$$
\mathrm{M}=\mathrm{p}_{1} \cdot \mathrm{L}_{1 \mathrm{~h}} \cdot\left(\mathrm{i}_{\mathrm{q}} \cdot \mathrm{i}_{\mathrm{dr}}-\mathrm{i}_{\mathrm{d}} \cdot \mathrm{i}_{\mathrm{qr}}\right)
$$

In (3), $\mathrm{M}_{\mathrm{m}}$ is resistant torque induction motor shaft, $\mathrm{J}$ is the moment of inertia related to the electric motor shaft and $\mathrm{p} 1$ is the number of stator pole pairs.

With the system of equations (1) and equation (3) determine the variation of the stator and rotor currents $\left(i_{d}(t), i_{q}(t), i_{d r}(t)\right.$ and $\left.i_{q r}(t)\right)$ and temporal variation rotor angular velocity $\omega(t)$.

Based on these sizes, it can be determined the real current of induction machine stator (Müller 2005):

$$
i=\sqrt{\frac{2}{3}} \cdot\left[i_{d} \cos \left(\omega_{1} t\right)-i_{q} \sin \left(\omega_{1} t\right)\right]
$$

If the induction machine with squirrel cage rotor winding tension axes are $\mathrm{d}$ and $\mathrm{q}$ is $\mathrm{u}_{\mathrm{dr}}=0$ and $\mathrm{u}_{\mathrm{qr}}=0$.

\section{PWM SUPPLY VOLTAGE}

In PWM, the converter output voltage frequency has the form of voltage pulses. To produce a balanced three-phase system voltage modulation, is it necessary an odd number of pulses $(2 p+1)$ for each half period.

Figure 2 shows the voltage wave form for one half cycles generalized to three-phase bridge inverter output (Muntean 1998).

The Fourier series expansion of the wave form shown in figure 2 is inferred the general case $[(2 p+1)$ pulses], $v$-order harmonic amplitude expression of voltage-phase traction motor:

$$
\begin{aligned}
& \mathrm{U}_{v}=\frac{8 \mathrm{U}_{\mathrm{D}}}{v \pi} \cos v\left(\alpha+\sum_{\mathrm{j}=1}^{\mathrm{p}} \alpha_{\mathrm{j}}\right) \cdot\left[\cos v\left(\sum_{\mathrm{j}=1}^{\mathrm{p}} \alpha_{\mathrm{j}}\right)-\cos v\left(\sum_{\mathrm{j}=2}^{\mathrm{p}} \alpha_{\mathrm{j}}\right)+\cos v\left(\sum_{\mathrm{j}=3}^{\mathrm{p}} \alpha_{\mathrm{j}}\right)+\right. \\
& \left.+\ldots+(-1)^{\mathrm{p}-1} \cos v \alpha_{\mathrm{p}}+(-1)^{\mathrm{p}} \frac{1}{2}\right]
\end{aligned}
$$




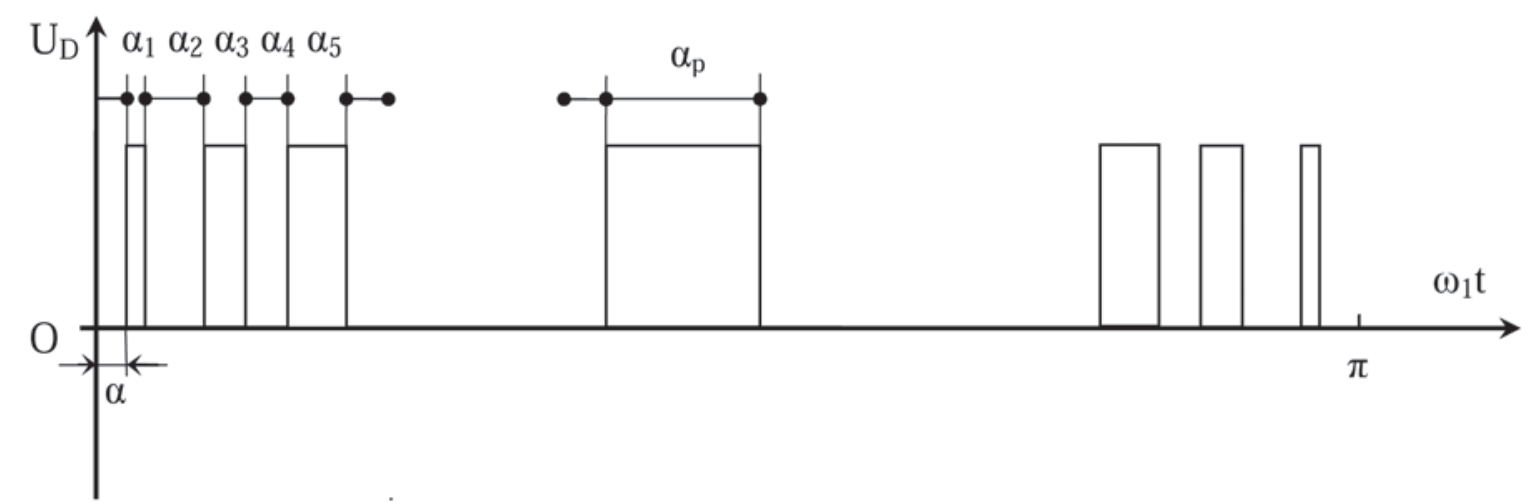

Figure 2 - Generalized waveform of the inverter output.

where: $\mathrm{U}_{\mathrm{D}}$ - the inverter input voltage;

$\mathrm{p}$ - number of pulses;

$\alpha_{j}-$ control angels.

For example, seven pulses per half cycle, the amplitude of the voltage harmonic of order $v$ is:

$$
\mathrm{U}_{v}=\frac{8 \mathrm{U}_{\mathrm{D}}}{v \pi} \cos v\left(\alpha+\sum_{\mathrm{j}=1}^{3} \alpha_{\mathrm{j}}\right) \cdot\left[\cos v\left(\sum_{\mathrm{j}=1}^{3} \alpha_{\mathrm{j}}\right)-\cos v\left(\sum_{\mathrm{j}=2}^{3} \alpha_{\mathrm{j}}\right)+\cos v \alpha_{3}-\frac{1}{2}\right]
$$

Relation (6) allows the elimination of groups of harmonics by appropriate choice of angles of order:

$\alpha_{1}, \alpha_{2}, \alpha_{3}, \ldots, \alpha_{p}$ of inverter switching elements.

The three-phase electric machines fed by frequency converters may occur in the order of these harmonics, rotate the order harmonics of the fundamental purposes of the magnetic field $(v=1)$, while rotating in the opposite order.

Variation in time of voltage for the three phases $(A, B, C)$ of the induction machine is determined by the relationship:

$$
\begin{aligned}
& \mathrm{u}_{\mathrm{A}}=\frac{8 \mathrm{U}_{\mathrm{D}}}{v \pi} \sum_{v=6 \mathrm{k} \pm 1}^{\infty} \frac{1}{v} \cdot \mathrm{E}(v) \cdot \mathrm{F}(v) \sin \left(v \omega_{1} \mathrm{t}\right) \\
& \mathrm{u}_{\mathrm{B}}=\frac{8 \mathrm{U}_{\mathrm{D}}}{v \pi} \sum_{v=6 \mathrm{k} \pm 1}^{\infty} \frac{1}{v} \cdot \mathrm{E}(v) \cdot \mathrm{F}(v) \sin \left(v \omega_{1} \mathrm{t}-\frac{2 \pi}{3}\right) \\
& \mathrm{u}_{\mathrm{C}}=\frac{8 \mathrm{U}_{\mathrm{D}}}{v \pi} \sum_{v=6 \mathrm{k} \pm 1}^{\infty} \frac{1}{v} \cdot \mathrm{E}(v) \cdot \mathrm{F}(v) \sin \left(v \omega_{1} \mathrm{t}-\frac{4 \pi}{3}\right)
\end{aligned}
$$

Where there were the following notations: 


$$
\begin{gathered}
E(v)=\cos v\left(\alpha+\sum_{j=1}^{3} \alpha_{j}\right) \\
F(v)=\left[\cos v\left(\sum_{j=1}^{p} \alpha_{j}\right)-\cos v\left(\sum_{j=2}^{p} \alpha_{j}\right)+\cos v\left(\sum_{j=3}^{p} \alpha_{j}\right)+\ldots+(-1)^{p-1} \cos v \alpha_{p}+(-1)^{p} \frac{1}{2}\right]
\end{gathered}
$$

According to transform Park (Boldea and Nasar 2002), the stator voltages in $\mathrm{d}$ and $\mathrm{q}$ axes of the machine are equivalent:

$$
\begin{aligned}
& u_{d}=\sqrt{\frac{2}{3}} \cdot\left[\begin{array}{l}
u_{A} \cos \left(\omega_{1} t\right)+u_{B} \cdot \cos \left(\omega_{1} t-\frac{2 \pi}{3}\right)+ \\
+u_{C} \cdot \cos \left(\omega_{1} t-2 \cdot \frac{2 \pi}{3}\right)
\end{array}\right] \\
& u_{q}=-\sqrt{\frac{2}{3}} \cdot\left[\begin{array}{l}
u_{A} \sin \left(\omega_{1} t\right)+u_{B} \cdot \sin \left(\omega_{1} t-\frac{2 \pi}{3}\right)+ \\
+u_{C} \cdot \sin \left(\omega_{1} t-2 \cdot \frac{2 \pi}{3}\right)
\end{array}\right]
\end{aligned}
$$

Through a mathematical calculation, relatively complicated, the machine equivalent of the stator voltages are set as:

$$
\begin{aligned}
& \mathrm{u}_{\mathrm{d}}=\frac{-4 \mathrm{U}_{\mathrm{D}}}{\pi} \sqrt{\frac{2}{3}} \cdot \mathrm{E}(1) \cdot \mathrm{F}(1)+\frac{8 \mathrm{U}_{\mathrm{D}}}{\pi} \cdot \sqrt{\frac{2}{3}} \sum_{\mathrm{k}=1}^{\infty}\left[\frac{\mathrm{A}_{\mathrm{k}} \mathrm{E}(6 \mathrm{k}+1) \mathrm{F}(6 \mathrm{k}+1)}{6 \mathrm{k}+1}+\frac{\mathrm{B}_{\mathrm{k}} \mathrm{E}(6 \mathrm{k}-1) \mathrm{F}(6 \mathrm{k}-1)}{6 \mathrm{k}-1}\right] \\
& \mathrm{u}_{\mathrm{q}}=\frac{-4 \mathrm{U}_{\mathrm{D}}}{\pi} \sqrt{\frac{2}{3}} \mathrm{E}(1) \cdot \mathrm{F}(1)-\frac{8 \mathrm{U}_{\mathrm{D}}}{\pi} \cdot \sqrt{\frac{2}{3}} \sum_{\mathrm{k}=1}^{\infty}\left[\frac{\mathrm{C}_{\mathrm{k}} \mathrm{E}(6 \mathrm{k}+1) \mathrm{F}(6 \mathrm{k}+1)}{6 \mathrm{k}+1}+\frac{\mathrm{D}_{\mathrm{k}} \mathrm{E}(6 \mathrm{k}-1) \mathrm{F}(6 \mathrm{k}-1)}{6 \mathrm{k}-1}\right]
\end{aligned}
$$

where:

$$
\begin{aligned}
& A_{k}=\sin \left(6 k \omega_{1} t\right)-\frac{1}{2} \sin \left[(6 k+2) \omega_{1} t\right] \\
& B_{k}=\sin \left(6 k \omega_{1} t\right)-\frac{1}{2} \sin \left[(6 k+2) \omega_{1} t\right] \\
& C_{k}=\cos \left(6 k \omega_{1} t\right)+\frac{1}{2} \cos \left[(6 k+2) \omega_{1} t\right] \\
& D_{k}=\cos \left(6 k \omega_{1} t\right)+\frac{1}{2} \cos \left[(6 k-2) \omega_{1} t\right], k \in N
\end{aligned}
$$


Voltages $\mathrm{u}_{\mathrm{d}}$ and $\mathrm{u}_{\mathrm{q}}$ are so determined, consisting of three components: a basic component (basic) containing the terms $\mathrm{E}(1)$ and $\mathrm{F}(1)$, the second component corresponding higher order harmonics rotating in direct sense $(6 \mathrm{k}+1)$, and the third component corresponding higher order harmonics, which rotate clockwise $(6 \mathrm{k}-1)$.

Substituting equations (13) and (14) in the system of equations (1) may determine the current in the stator winding, rotor speed, electromagnetic torque, stator and rotor flows depending on the number of pulses, the inverter control angle, frequency and induction machine load

\section{CASE STUDY}

Figure 3 shows a trolley powered by a three-phase induction motor manufactured by the company ASTRA Bus Arad, Romania (Rădulescu et al. 2007). Principle and the inverter schematics required to change speed induction motor are shown in Figure 4.

Phase induction machine with squirrel cage is having a $P_{N}=160 \mathrm{~kW}$ rated power, $U_{N}=420 \mathrm{~V}$ nominal voltage and rated speed $\mathrm{n}_{\mathrm{N}}=1470 \mathrm{rpm}$.

Electrical parameters for the induction machine are: $\mathrm{R}_{1}=0,0285 \Omega ; \mathrm{R}_{2}=0,01826 \Omega ; \mathrm{L}_{1 \sigma}=9,444 \times 10^{-5} \mathrm{H}$; $\mathrm{L}_{2 \sigma}=5,838 \times 10^{-5} \mathrm{H} ; \mathrm{L}_{1 \mathrm{~h}}=9,3088 \times 10^{-3} \mathrm{H} ; \mathrm{J}=69,445 \mathrm{kgm}^{2}$.

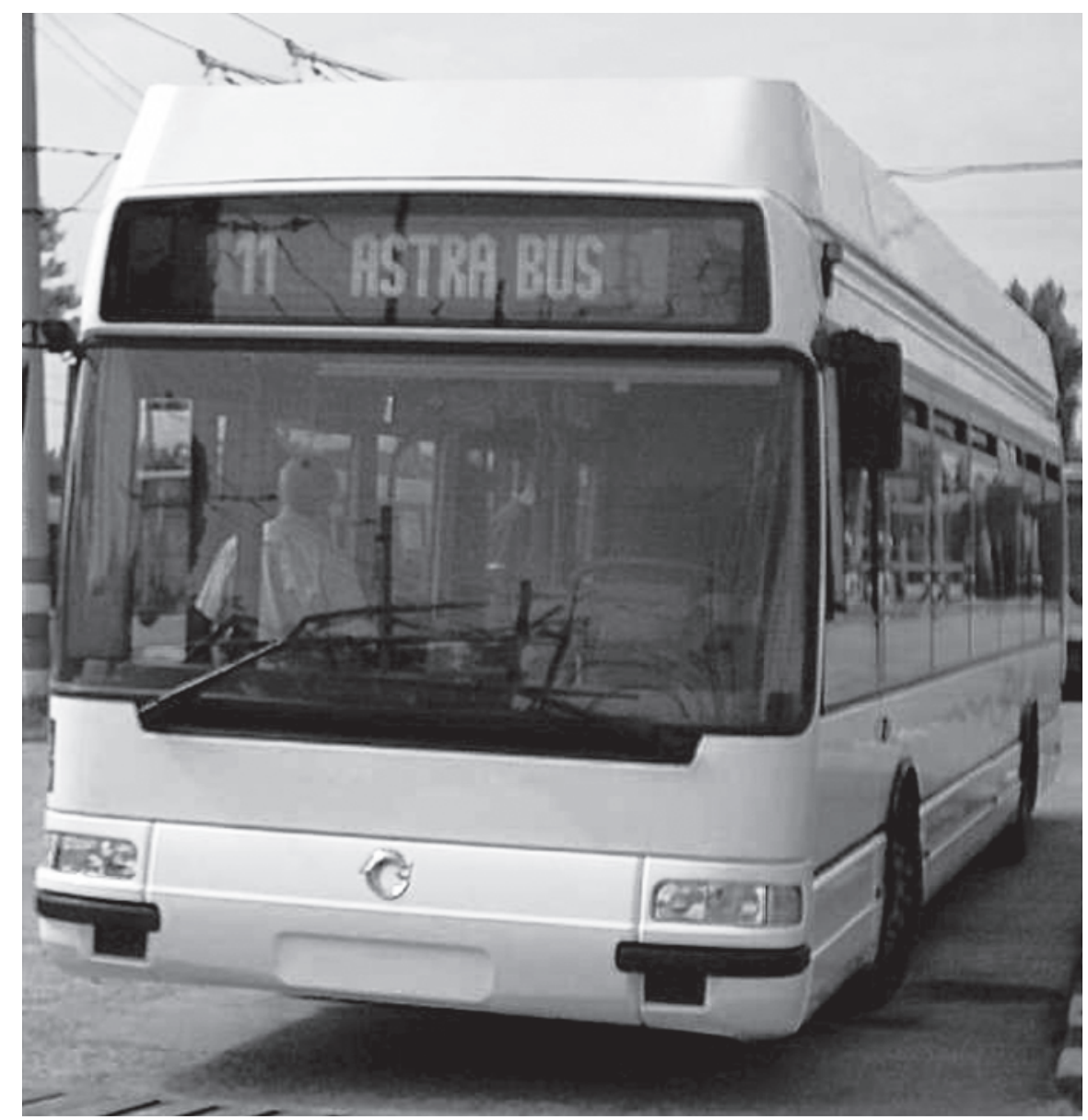

Figura 3 - Trolley powered by a three-phase induction motor (Rădulescu et al. 2007). 


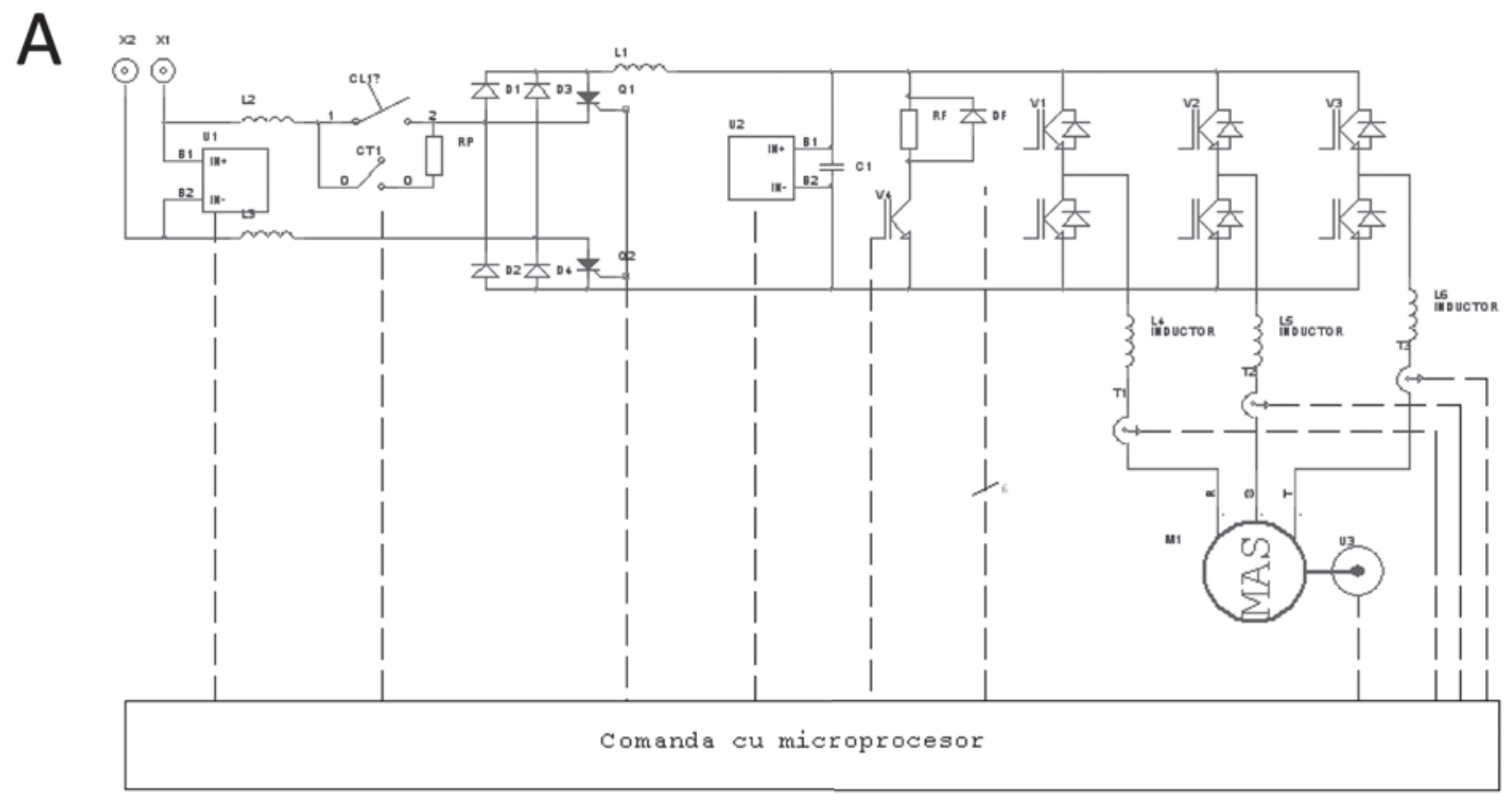

B

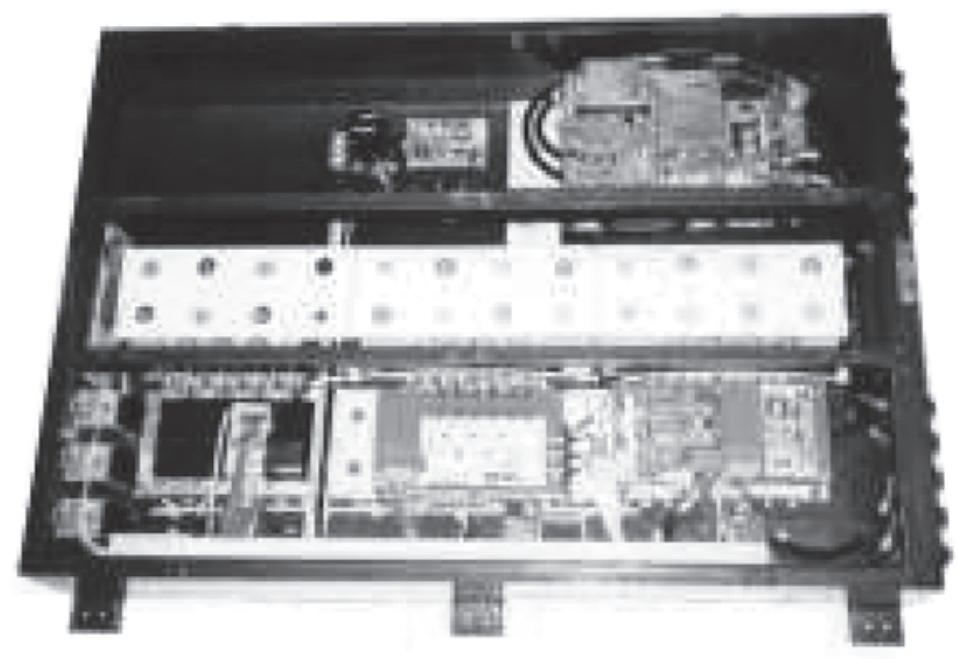

Figure 4 - Power control scheme (A) Structural and inverter (INV 500) required changing speed induction motor trolley (B) (Rădulescu et al. 2001).

Figure 5 shows the operating characteristics of electric traction motor frequency $\mathrm{f}_{1}=10 \mathrm{~Hz}$, the inverter voltage $\mathrm{U}_{\mathrm{D}}=192 \mathrm{~V}$ and torque resistant tree $\mathrm{M}_{\mathrm{m}}=1039 \mathrm{Nm}$. PWM supply voltage of the electric motor is carried out for seven pulses per half period, with the following control angles switching elements: $\alpha=10^{\circ}$; $\alpha_{1}=3,22^{\circ} ; \alpha_{2}=11,09^{\circ} ; \alpha_{3}=7,87^{\circ}$. This command lets you remove the harmonics of order 5,11 and 13 .

Figure 6 presents the operating characteristics of electric traction motor power under the same conditions $\left(f_{1}=10 \mathrm{~Hz}, \mathrm{U}_{\mathrm{D}}=192 \mathrm{~V}\right)$, but for five pulses per half cycle, with control angles: $\alpha=10^{\circ} ; \alpha 1=6,18^{\circ} ; \alpha_{2}=$ $10,86^{\circ}$. This command lets you remove the harmonic order 5 and 11. 


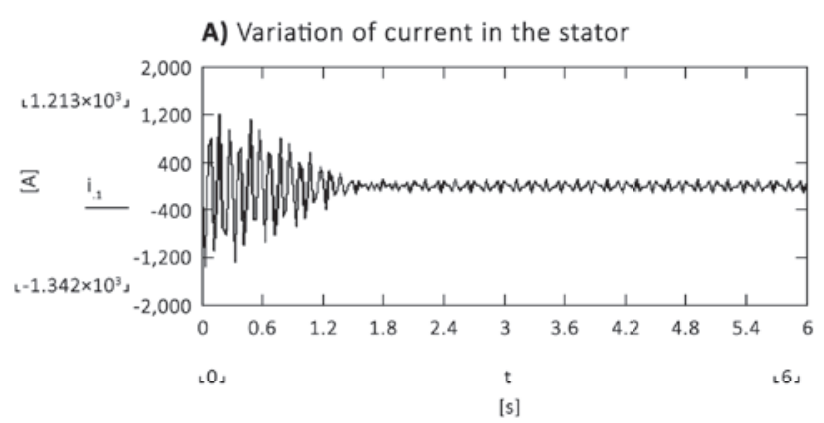

C) Mechanical characteristics of the eletric motor

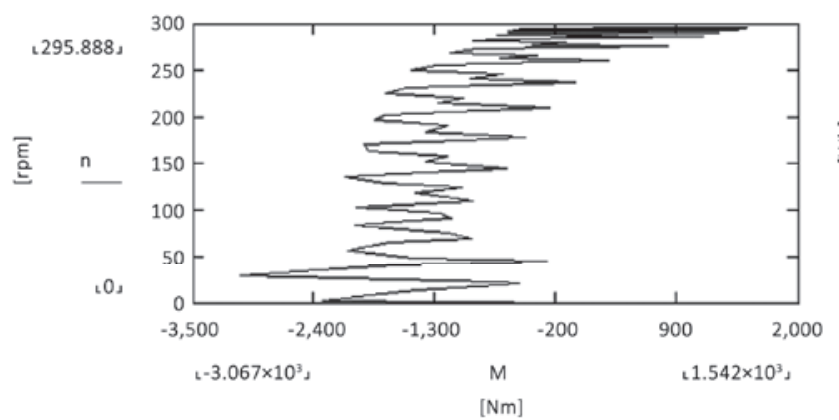

E) The rotor magnetic flux

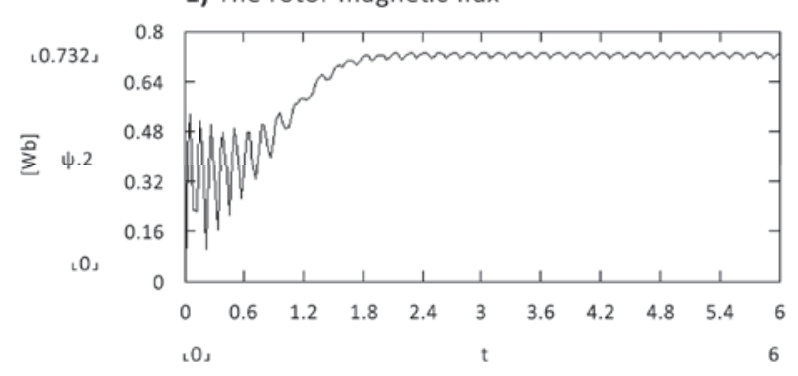

[s]
B) Detail of speed oscillations

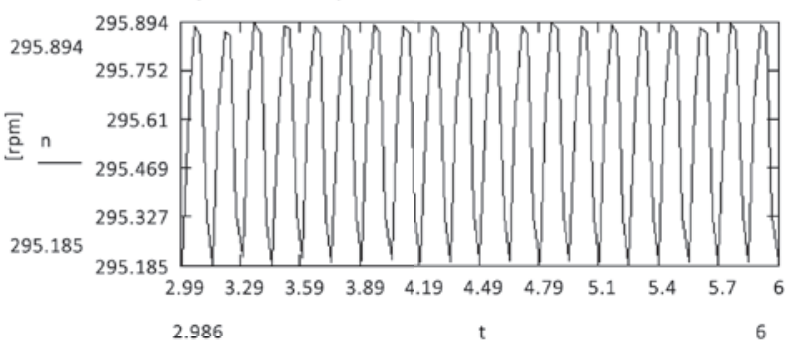

[s]

D) Magnetic flux in the stator

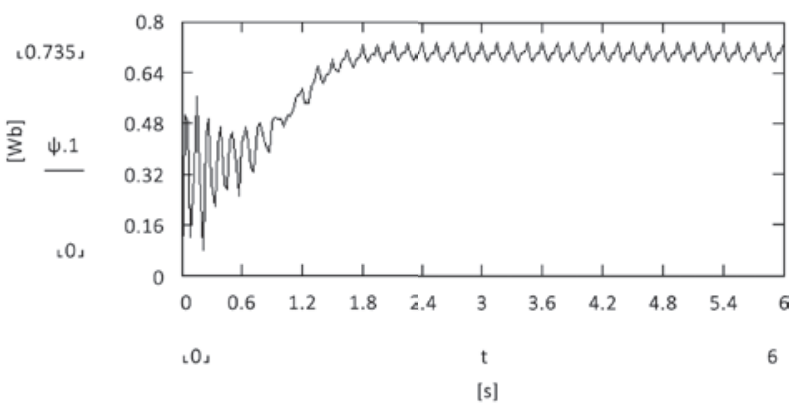

Figure 5 - Operating characteristics of induction motor for PWM seven pulses per half cycle.

\section{CONCLUSIONS}

1. At low speeds, when a supply voltage of the traction motor is less than $20 \mathrm{~Hz}$, pulsating torque caused by higher harmonics of the rotor produces a jerky motion, practically confined to the lower speed power tool that can be used; 2. Improving the performance of electric traction motor, it can be achieved by eliminating the higher harmonics or higher harmonics of groups in the number of pulses and control mode of inverter switching elements; 3. Improving the performance of electric traction motor can be achieved by eliminating the higher harmonics or higher harmonics of groups in the number of pulses and control mode of inverter switching elements; 4. Wave machine supplies power voltage induction, set down in Park's theory and was divided into three components: the fundamental component $(v=1)$, direct sequence component $(v=6 \mathrm{k}+1)$ and negative sequence component $(v=6 \mathrm{k}-1)$. In this way, we can determine which adversely affects the operation of harmonic induction motor; 5. Figures 5 and 6 reveal the influence of higher harmonics on the operating characteristics of three phase induction motor used to drive electric trolley; 6 . Figures $5 \mathrm{~b}$ and $6 \mathrm{~b}$ comparison shows that the presence of 13 order harmonics oscillations determined to double the speed for when this harmonic is eliminated. 
A) Variation of current in the stator

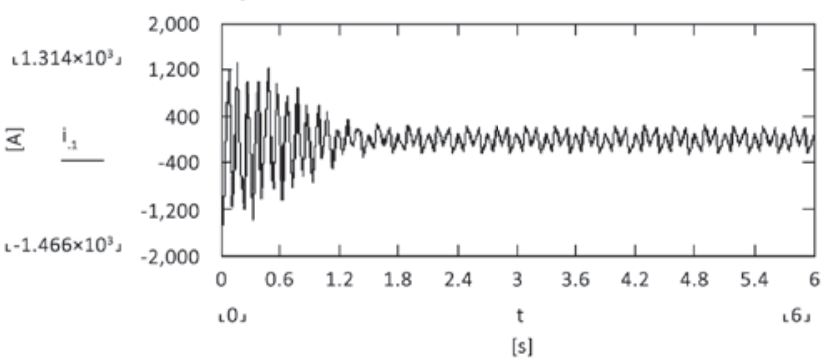

C) Mechanical characteristics of the eletric motor

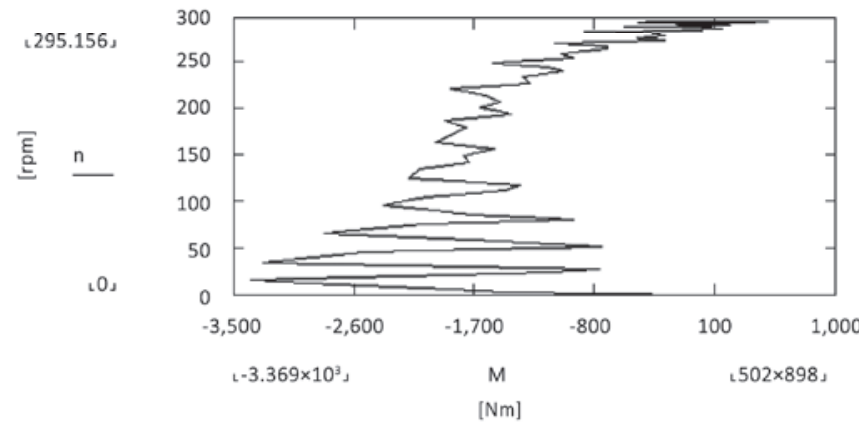

E) The rotor magnetic flux

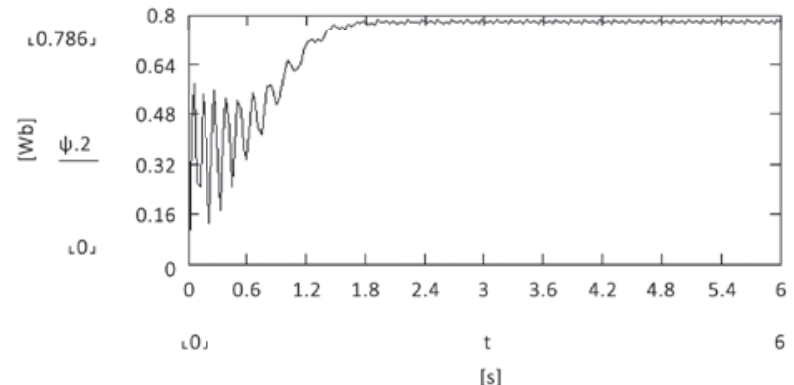

B) Detail of speed oscillations

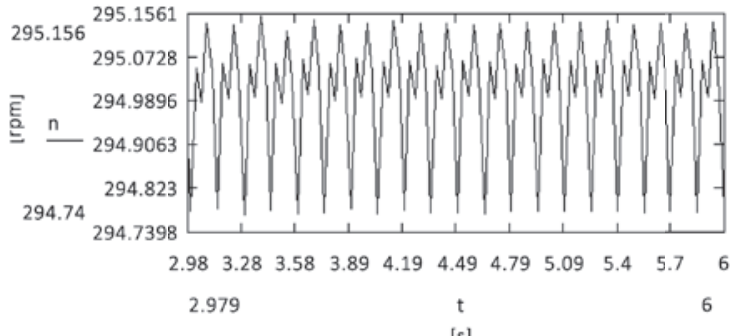

D) Magnetic flux in the stator

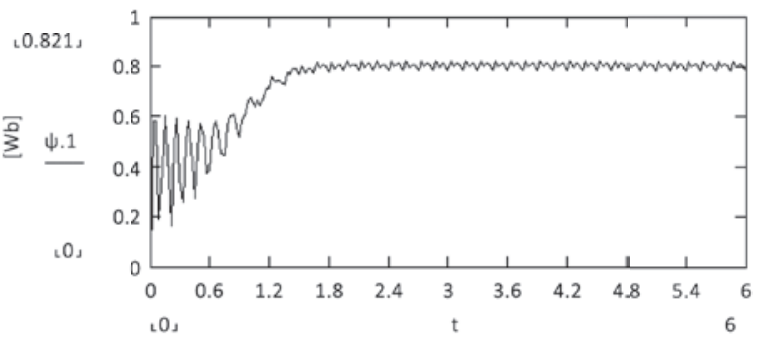

[s]

Figure 6 - Operating characteristics of induction motor for PWM five pulses per half cycle.

\section{RESUMO}

Este documento estabelece um modelo matemático de máquina de indução conectado a um inversor de frequência necessário para ajustar o motor de acionamento elétrico. O modelo matemático baseado na Teoria de Park permite a análise de todo o espectro (carro elétrico com inversor de frequência) para dirigir o ônibus elétrico feito em ASTRA Bus Arad (Romênia). Para remover harmônicas de ordem mais alta, a forma de onda da tensão de alimentação PWM é utilizado, definido no caso geral. Características de funcionamento do motor de acionamento elétrico são definidas para frequência sub-nominal ( $\mathrm{f}<50 \mathrm{~Hz}$ ), e para diferentes ângulos de controle da comutação de elementos de construção do inversor. Tensões no estator da máquina equivalente é determinado por três componentes: o componente fundamental; segundo componente correspondente à maior harmônicas de ordem, que giram em conexão direta, e os terceiros componentes de maior harmônicas de ordem, que são giradas em sentido inverso. O modelo matemático desenvolvido vai ajudar a determinar as harmônicas que têm uma influência negativa sobre o desempenho do motor elétrico e também determina o ângulo de controle dos elementos de comutação para remover essas harmônicas.

Palavras-chave: motor de indução, características de funcionamento, modelo matemático, ônibus elétrico (tróleis). 


\section{REFERENCES}

BELE I. 2007. The Technical Book of The Trolleybus, SC Astrabus Arad.

BoldEA I AND NASAR AS. 2002. The Induction Machine Handbook, CRC Press, chapter 13.

DORdEA T. 2002. Maşini Electric. Editura ASAB București, p. 129-138.

MÜLLER V. 2005. Mașini Electrice. Editura Politehnica Timișoara, p. 93-97.

Muntean N. 1998. Convertoare Statice. Editura Politehnica Timişoara, p. 175-184.

PĂPUȘOIU GH. 2003. Eletrotehnică Industrială, Editura Orizonturi Universitare Timişoara, p. 243-249.

RĂdulescu V, STRĂINescu I, Tudor E, Bele I, Bocî LS AND GAVRA C. 2007. Testing experimental models for an advanced electrical traction system with frequency inverters, Scientific Bulletin of the "Politehnica" University of Timisoara, Romania, Transactions on Mechanics, Tom 52(66) ISSN 1224- 6077, Fasc. 7.

RĂDULeSCU V ET AL. 2001. Power variating device equipment using IGBT transistors for trolleybuses driving, Patent request $\mathrm{N}^{\circ}$. A / 009/08.2001. 